\title{
Anti-inflammatory Effect of Polysaccharide Derived from Commercial Kanjang on Mast Cells
}

\author{
Yu-Jin Ko, Gyeong-Ran Lee and Chung-Ho Ryu*
}

Division of Applied Life Science, Institute of Agriculture and Life Science, Gyeongsang National University, Jinju 660-701, Korea

Received February 5, 2013 /Revised April 15, 2013 /Accepted April 19, 2013

\begin{abstract}
Soy sauce is a traditional fermented seasoning in several oriental countries, such as Korea and Japan, and recently it has been reported to have biological activities. In Korean soy sauce, soybeans and wheat are the two main raw materials. Polysaccharides that originate from the cell wall of soybeans are resistant to enzymatic hydrolysis. These polysaccharides remain in the soy sauce even after fermentation and are termed Kanjang polysaccharides (KPS). In this study, polysaccharides were obtained from dialysate of different soy sauces labeled as $A \sim T$ and manufactured by fermentation or the acid-hydrolyzate method. We investigated anti-inflammatory activities by examining the effects of these KPS on proinflammatory cytokine release and mRNA expression in mast cells. Histamine and $\beta$-hexosaminidase release were strongly decreased by the KPS treatment in RBL-2H3 cells. Treatment with KPS clearly reduced mRNA expression and the release of the proinflammatory cytokines interleukin (IL)-6, IL-8, and tumor necrosis factor-alpha (TNF-a) in PMACI-stimulated HMC-1 cells. In particular, KPS derived from fermented Kanjang products showed a significant anti-inflammation effect on mast cells compared to the acid-hydrolyzed Kanjang products. This study suggests that KPS appear to be effective in suppressing allergic inflammatory reactions.
\end{abstract}

Key words : Anti-inflammatory effect, cytokine, Kanjang, mast cell, polysaccharide

\section{서 론}

최근 산업화, 도시화의 심화로 변화된 주거환경, 식생활의 변화, 유전적인 영향, 환경오염에 의해 발생되는 화학적, 생물 학적 유해인자들에 대한 노출은 다양한 연령층에서의 염증성 알레르기 질환을 크게 증가시키고 있다[7]. 이는 인체가 무해 한 외부환경에 대해서도 민감한 반응을 보이며, 지속적으로 천식이나 비염과 같은 호흡기계 또는 만성 피부염증, 아토피 질환 등의 피부계 증상 등으로 생활에 악영향을 미치는 것으 로 알려져 있다[6, 16].

염증 반응은 생체에 이물질이 감염 또는 침입하였거나 물리 화학적 손상을 입었을 때 이를 방어하기 위한 국소적 현상이 지만, 과잉의 생체 방어 반응은 염증 국소 주위에 있는 정상 조직을 손상시켜 염증 질환을 일으킨다[32]. 비만세포는 아토 피 피부염, 기관지 천식, 알레르기성 비염과 같은 염증반응에 관련되는 주요 세포 중 하나[2]로써 $\mathrm{IgE}$ 매개 면역반응과 관계 되어 있으며, $\mathrm{T}_{\mathrm{H}} 2$ type에 의존적인 면역과민성 반응과 알레르

\footnotetext{
*Corresponding author

Tel : +82-55-772-1905, Fax : +82-55-772-1909

E-mail : ryu@gnu.ac.kr

This is an Open-Access article distributed under the terms of the Creative Commons Attribution Non-Commercial License (http://creativecommons.org/licenses/by-nc/3.0) which permits unrestricted non-commercial use, distribution, and reproduction in any medium, provided the original work is properly cited.
}

기성 질환 및 특정 선천성 면역반응을 유도하는 것으로 알려 져 있다[36]. 특히 외부자극으로부터 활성화된 비만세포는 histamine과 같은 혈관확장물질들을 분비하며, 염증유발물질 인 다양한 IL-6, IL-8, IL-13, TNF-a와 같은 cytokine 분비를 자극한다[26].

항히스타민 약물의 사용은 면역학적 또는 비면역학적 과 민반응 증상을 일시적으로 완화시키지만 완전히 치료되지 는 않는다 $[9,29,30]$. 따라서 알레르기 매개물질인 histamine 방출을 예방하는 소재의 개발이 요구되고 있으며, 천 연물 소재는 장기간 복용이 가능하고 부작용의 위험이 적으 므로 다양한 천연식물을 이용한 효능 검색이 활발하게 이루 어지고 있다[18].

식물을 이용한 약리성분은 주로 열수 추출법으로 이용되어 왔는데 이러한 추출물 중에는 alkaloid, flavonoid 및 saponin 과 같은 저분자 물질과 다당류, 단백질 등과 같은 고분자 물질 이 다양하게 존재한다. 저분자 물질의 생리활성에 관한 연구 는 비교적 상세히 진행되어 왔지만, 이들 중 대부분의 물질은 물에 난용성으로 식물 추출물이 가지는 모든 약리활성을 나타 낸다고 할 수 없다. 최근 식품 및 생약의 열수추출물 중 고분자 획분에서 다양한 약리활성이 관찰되고 있고 $[5,31,34,37]$, 특 히 식물유래 다당에서 높은 면역증진 활성이 보고되고 있는 데, 이들은 비교적 낮은 독성을 나타내며 효율적인 치료 효과 $[24,33,35]$ 를 갖고 있어 의약품, 건강 보조 기능성 식품 소재로 응용이 가능할 것으로 생각되고 있다. 기능성 다당류에 관한 
연구로는 버섯유래의 고분자 다당류[23,38], 해조류 추출 다당 류[11] 등에 관한 연구가 주를 이루고 있으나, 최근에는 한약재 유래[27], 술, 식초 등의 발효식품 유래 다당류[4, 10] 등 그 연구범위가 넓어지고 있다.

최근 대두의 세포벽에서 유래한 다당류의 정제와 특성에 관한 연구[8]가 이루어지고 있는 가운데, 우리나라의 대표적인 콩 발효식품인 장류는 콩 단백질의 분해와 동시에 미생물이 분비하는 효소가 축적되어 대두의 다당류가 더욱 효율적으로 추출될 것이라 사료된다. 이러한 전통발효식품인 장류에는 간 장, 된장, 혼합장 등이 있으며[17], 특히 간장은 메주의 염수추 출로 인해 대두 다당류가 수용액 중에 다량 용출된다. 일본에 서는 일본식 간장인 쇼유에서 추출한 Shoyu polysaccharide의 immunomodulating 활성[21]과 항알레르기 활성[15]에 관한 연구가 활발하게 진행되어 있으나, 우리나라 간장의 경우 원 료와 제조방법이 쇼유와 상이하여 더욱 높은 기능성 다당류의 발견이 예상되지만 아직 그 연구가 이루어지지 않고 있는 실 정이다.

이에 본 연구에서는 한국 시판 간장을 대상으로 기능성 다 당류를 분리하고 인간유래 비만세포에 처리한 후 염증반응의 원인인 histamine과 $\beta$-hexosaminidase의 분비량 및 염증성 cytokine IL-6, IL-8, TNF- $a$ 의 유리량을 측정함으로써 한국식 간장의 항염증 효과를 규명하고 우리나라 전통 장류의 우수성 을 검증하고자 하였다.

\section{재료 및 방법}

\section{간장의 일반성분 분석}

간장의 일반성분은 다음과 같은 방법으로 분석하였다. $\mathrm{pH}$ 는 $\mathrm{pH}$ meter (Orion 420A, Thermo, Beverly, MA, USA)를 이용하여 측정하였으며, 염도는 간장 10 배 희석액 $10 \mathrm{ml}$ 을 취 하여 $2 \% \mathrm{~K}_{2} \mathrm{CrO}_{4} 1 \mathrm{ml}$ 을 넣고 $0.1 \mathrm{~N} \mathrm{AgNO}_{3}$ 로 적정하였다. 총 질소는 식품공전에 따라 Kjeldahl법으로 측정하였으며, 아 미노태 질소 함량은 $\mathrm{AOAC}$ 에 제시된 방법으로 측정하였다. 총당 함량은 간장 시료 $1 \mathrm{ml}$ 에 5\% phenol (Yakuri pure chemicals Co., Ltd., Kyoto, Japan) 1 ml와 $\mathrm{H}_{2} \mathrm{SO}_{4}$ (Samchyn pure chemicals Co., Ltd., Pyeongtaek, Korea) $5 \mathrm{ml}$ 를 가하여 상온 에서 30 분간 반응시킨 후 $460 \mathrm{~nm}$ 에서 흡광도를 측정하였고, 표준물질로는 glucose (Sigma Chemical Co., St. Louis, MO, USA)를 사용하였다. 환원당 함량은 시료 $1 \mathrm{ml}$ 에 $0.75 \%$ 3,5-dinitrosalicylic acid (DNS, Sigma Chemical Co., St. Louis, MO, USA) 용액 $1 \mathrm{ml}$ 을 첨가하고 $100^{\circ} \mathrm{C}$ 에서 5 분간 반응시킨 다음 증류수 $8 \mathrm{ml}$ 을 가한 후 $540 \mathrm{~nm}$ 에서 흡광도를 측정하였다.

\section{간장 다당류(Kanjang polysaccharide, KPS)의 추출}

간장 다당류의 추출을 위하여 국내 시판중인 간장 제품 $\mathrm{A} \sim \mathrm{T}$ 를 수집하여 실험에 사용하였으며 이중 $\mathrm{A} \sim \mathrm{L}$ 은 양조간장,
$\mathrm{M} \sim \mathrm{T}$ 는 산분해 간장으로 분류하였으며, 특히 $\mathrm{F}$ 와 $\mathrm{K}$ 는 재래식 국간장으로 제조된 제품이었다. 수집된 간장은 Kikuchi [12]의 방법에 의하여 다당류를 추출하였다. $10 \mathrm{ml}$ 의 간장을 cellulose membrane (Width. 43 mm, Diameter. 27 mm, 12,000 molecular weight, Dialysis membrane, Viskase Corporation, Chicago, Illinois, USA)을 이용하여 $4^{\circ} \mathrm{C}$ 의 물에서 overnight하 여 투석한 후 동결 건조하여 KPS를 추출하였다.

\section{세포 배양}

Human mast cell세포(HMC-1, a kind gift from Dr. H.M. Kim at Kyeonghee University, Seoul, Korea)는 10\% Fetal bovine serum (FBS), $100 \mathrm{U} / \mathrm{ml}$ penicillin과 $100 \mathrm{\mu g} / \mathrm{ml}$ streptomycin이 함유된 Isocove's modified Dulbecco's medium (IMDM, Gibco BRL, NY, USA)를 이용하여 $37^{\circ} \mathrm{C}, 5 \% \mathrm{CO}_{2}$ 에서 배양하였다. Rat basophilic leukemia 세포(RBL-2H3, Korean Cell Line Bank No. 22256)는 10\% Fetal bovine serum (FBS), $4 \mathrm{mM}$ L-glutamine, $100 \mathrm{U} / \mathrm{ml}$ penicillin과 $100 \mu \mathrm{g} / \mathrm{ml}$ streptomycin이 함유된 Dulbecco's modified eagle medium (DMEM, Gibco BRL, NY, USA)를 이용하여 $37^{\circ} \mathrm{C}, 5 \% \mathrm{CO}_{2}$ 에서 배양하였다.

\section{세포 생존율 측정}

세포의 생존율은 3-(4,5-dimethylthiazol-2-yl)-2,5-diphenyltetrazolium bromide (MTT) assay로 실험하였다[14]. 세포 $\left(5 \times 10^{5} \mathrm{cell} / \mathrm{ml}\right)$ 에 KPS를 $1 \mathrm{mg} / \mathrm{ml}$ 로 조절하여 $500 \mu \mathrm{ll}$ 의 배양 액에 $5 \mu 1$ 를 처리하고 $30 \mathrm{~min}$ 간 incubator에서 반응 후 Phorbol 12-myrostate 13-acetate (PMA, Sigma-Aldrich, St. Louis, MO, USA)와 calcium ionophore A23187 (SigmaAldrich, St. Louis, MO, USA)을 $8 \mathrm{hr}$ 동안 자극하였다. 자극 후 MTT solution $(50 \mu l)$ 를 첨가하여 $37^{\circ} \mathrm{C}$ 에서 overnight하고 dimethyl sulfoxide (DMSO)로 결정을 녹인 후 $540 \mathrm{~nm}$ 에서 흡광도를 측정하였다. KPS와 자극제를 처리하지 않은 무 처리 구의 흡광도를 $100 \%$ 로 하여 세포 생존율을 계산하였다.

\section{Histamine 유리억제율 측정}

RBL-2H3 세포 배양 상징핵 중에 있는 histamine의 정량은 Shore [28]의 방법에 따라 에펜돌프 튜브에 배양액 $500 \mu 1$ 를 넣고 $0.1 \mathrm{~N}-\mathrm{HCl} 450 \mu \mathrm{ll} 60 \%$ 과염소산 용액 $50 \mathrm{ml}$ 를 넣고 혼합 후 원심분리 $(15,000 \mathrm{rpm}, 20 \mathrm{~min})$ 하여 그 상징액 $800 \mu 1$ 를 5 $\mathrm{N}-\mathrm{NaOH}$ 용액 $500 \mu \mathrm{l}$, 증류수 $3 \mathrm{ml}, \mathrm{n}$-butanol $10 \mathrm{ml}$ 및 $\mathrm{NaCl}$ $1.2 \mathrm{~g}$ 을 혼합한 시험관에 넣고 진탕 $(20 \mathrm{~min}$ 이상 $)$ 후 원심분리 $(2,000 \mathrm{rpm}, 10 \mathrm{~min})$ 하였다. Butanol층 $8 \mathrm{ml}$ 를 $50 \mathrm{ml}$ 시험관에 넣고 $0.1 \mathrm{~N}-\mathrm{HCl}$ 용액 $3 \mathrm{ml}, \mathrm{n}$-heptane $10 \mathrm{ml}$ 를 가하여 진탕(20 $\min$ 이상)후에 원심분리 $(2000 \mathrm{rpm}, 10 \mathrm{~min})$ 하였다. 여기에서 얻어진 수층 $2 \mathrm{ml}$ 에 $1 \mathrm{~N}-\mathrm{NaOH}$ 용액 $400 \mu \mathrm{l}$ 와 $1 \% O$-phthaldialdehyde (Sigma, St. Louis, MO, USA)용액 $100 \mu 1$ 를 넣고 
수옥상 $\left(37^{\circ} \mathrm{C}\right)$ 에서 $3 \mathrm{~min}$ 동안 반응시킨 다음, $3 \mathrm{~N}-\mathrm{HCl}$ 용액 $200 \mu 1$ 를 넣고 혼합 후에 $2 \mathrm{~min}$ 동안 방치하여 spectro-

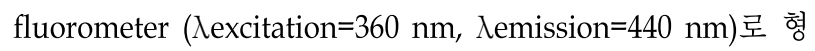
광도를 측정하였다. Histamine 유리억제율(\%)은 다음과 같이 계산하였다.

$$
\text { 억제율 }(\%)=\{(\mathrm{A}-\mathrm{B}) / \mathrm{A}\} \times 100
$$

- A: KPS를 부가하지 않았을 때의 histamine양

- B: KPS를 부가하였을 때의 histamine양

\section{$\beta$-hexosaminidase 유리억제율 측정}

비만세포의 탈과립은 granule marker인 $\beta$-hexosaminidase 의 측정을 통해 조사하였다. RBL-2H3 세포를 24 well plate에 $1 \times 10^{6}$ cells/well로 seeding한 후 overnight로 배양하였다. 세 포는 3회간 siraganian buffer $(125 \mathrm{mM} \mathrm{NaCl}, 5 \mathrm{mM} \mathrm{KCl}, 1.5$ $\mathrm{mM} \mathrm{CaCl}, 1.5 \mathrm{mM} \mathrm{MgCl}, 20 \mathrm{mM} \mathrm{HEPES}, \mathrm{pH}$ 7.3)로 세척한 후 $0.1 \%$ 의 Bovine serum albumin (BSA)를 함유한 $500 \mu 1$ 의 siraganian buffer에 현탁한 후 $400 \mathrm{ng} / \mathrm{ml}$ 의 dinitrophenolbovine serum albumin (DNP-BSA)로 자극하여 $37^{\circ} \mathrm{C}$ 에서 1 $\mathrm{hr}$ 동안 배양하였다. 그 후 $50 \mu \mathrm{l}$ 의 상징액을 $1 \mathrm{mM} \mathrm{p}$-nitropenyl N-acetyl- $\beta$-D-glucosamine (Sigma, St. Louis, MO, USA)을 함유한 $200 \mu 1$ 의 $0.05 \mathrm{M}$ citrate buffer (pH 4.5)에 혼합 한 후 $37^{\circ} \mathrm{C}$ 에서 $3 \mathrm{hr}$ 동안 배양하였다. $500 \mu \mathrm{l}$ 의 $0.05 \mathrm{M}$ sodium carbonate buffer $(\mathrm{pH} 10.0)$ 를 첨가하여 효소반응을 종결한 후 $405 \mathrm{~nm}$ 에서 흡광도를 측정하였다. $\beta$-hexosaminidase 유리에 대한 KPS 처리의 효과는 다음과 같이 억제율로 계산하여 나타 내었다.

억제율 $(\%)=($ Treated-Blank-Spontaneous)/(Control-Blank -Spontaneous)

- Control: KPS를 부가하지 않았을 때의 normal allergen-IgE response

- Treated: KPS를 부가하였을 때의 normal allergen-IgE response

- Blank: KPS와 기질만 ELISA well에 첨가
- Spontaneous: KPS를 부가하지 않았을 때의 allergen-IgE response

\section{Cytokine 분비량 측정}

KPS의 항염증 효과를 알아보기 위해 HMC-1 세포에 KPS를 $1 \mathrm{mg} / \mathrm{ml}$ 농도로 처리한 후 PMA와 A23187로 자극하여 유도 된 cytokine (IL-6, IL-8와 TNF-a) 분비량을 ELISA법으로 측정 하였다. 96 well plate에 IL-6, TNF- $a$ 와 IL-8의 monoclonal antibody (BD Pharmingen, San Diego, CA, USA) 를 넣어 $4^{\circ} \mathrm{C}$ 에 서 하룻밤 코팅하였다. $0.05 \%$ Tween20을 첨가한 phosphate buffer saline (PBST)로 세척한 후 standard로 사용되는 recombinant IL-6, TNF-a, IL-8과 시료를 각각 첨가하여 실온에 서 $2 \mathrm{hr}$ 동안 반응시킨다. 세척 후 biotinylated anti-human IL-6, TNF- $a$ 와 IL-8을 첨가하여 실온에서 $2 \mathrm{hr}$ 동안 반응시킨 다음 avidin peroxidase를 넣어 $40 \mathrm{~min}$ 간 반응시킨 후 2,2'-azino- bis (3-ethylbenzthiazoline-6-sulfonic acid) (ABTS, Sigma, St. Louis, MO, USA)를 첨가하여 $405 \mathrm{~nm}$ 에서 측정하 였다.

\section{Cytokine mRNA 발현량 측정}

세포의 Total RNA 분리는 easy-BLUE Total RNA Extraction Kit (iNtRON Biotechnology, INC, Beverly, MA, $\mathrm{USA}$ )를 사용하였으며, 분리된 total RNA을 이용하여 cDNA 를 합성한 후, 이 cDNA를 주형으로 Cytokine specific primer (Table 1)을 이용하여 PCR를 실시하였다. 이 때 대조구로 $\mathrm{GAPDH}$ 를 사용하였으며, 얻어진 DNA 생성물은 $2 \%$ agarose gel에서 전기영동 후 ethidium bromide로 염색하여 UV하에 서 관찰하였다.

\section{통계학적 분석}

모든 실험은 3 회 반복실험을 실시하여 평균치와 표준편차 로 나타내었으며, 실험결과의 통계처리는 SPSS (Statistical Package for Social Science for Windows, Rel 18.0) program을

Table 1. Primers and PCR conditions for analysis of gene expression in HMC-1

\begin{tabular}{llcc}
\hline Cytokines & \multicolumn{1}{c}{ Primer sequence $\left(5^{\prime} \rightarrow 3^{\prime}\right)$} & $\begin{array}{c}\text { Annealing } \\
\text { Temperature }\left({ }^{\circ} \mathrm{C}\right)\end{array}$ & $\begin{array}{c}\text { Amplified Size } \\
(\mathrm{bp})\end{array}$ \\
\hline \multirow{2}{*}{ TNF-a } & $\begin{array}{l}\text { 5'-CCT ACC AGA CCA AGG TCA AC-3' } \\
\text { 5'-AGG GGG TAA TAA AGG GAT TG-3' }\end{array}$ & 57 & 279 \\
\hline \multirow{2}{*}{ IL-6 } & $\begin{array}{l}\text { 5'-AAA GAG GCA CTG GCA GAA AA-3' } \\
\text { 5'-ATC TGA GGT GCC CAT GCT AC-3' }\end{array}$ & 59 & 412 \\
\hline \multirow{2}{*}{ IL-8 } & 5'-TGAATTCTCAGCCCTCTTCAAAAA-3' & 443 \\
\hline 5APDH & 5'-CGATGTCAGTGCATAAAGACA-3' & 59 & 446 \\
\hline
\end{tabular}


이용하여 분산분석을 실시하였다. 세포의 자극 후와 KPS의 처리에 의한 효과를 검증하기 위하여 Duncan's multiple range test로 사후검정을 수행하였으며 $p<0.05$ 를 유의수준으 로 평가하였다.

\section{결과 및 고찰}

\section{간장의 품질특성 및 다당류 KPS의 수율}

간장 다당류 수율 탐색을 위한 기초자료의 제시를 위한 간 장의 품질 특성을 조사하기 위하여 국내 시판 간장의 일반 성분을 측정한 결과를 Table 2에 나타내었다. 대부분의 간장 제품의 $\mathrm{pH}$ 는 4.56 5.08로 간장의 $\mathrm{pH}$ 는 큰 차이가 없는 것으로 나타났다. 간장의 담금 기간이 경과할수록 간장덧 중에 존재 하는 젖산균 등의 산 생성 미생물에 의해 유기산이 생성되어 산도가 증가된다고 보고되어 있는데, 산 분해 간장인 $\mathrm{M} \mathrm{T}$ 제 품의 $\mathrm{pH}$ 의 경우 $4.73 \sim 5.08$ 로 양조간장 구에 비해 $\mathrm{pH}$ 가 약간 높은 것으로 나타나 간장의 제조방법이 간장의 $\mathrm{pH}$ 에 영향을 미치는 것을 확인할 수 있으며, 이러한 $\mathrm{pH}$ 의 차이는 대두로부 터 용출되어 나오는 다당류의 생산 수율에도 영향을 미칠 것 이라 사료된다. 시판 간장의 염도는 약 $13.0 ~ 21.8 \%$ 로 나타났으 며 $\mathrm{A} \sim \mathrm{L}$ 의 양조간장은 $13.0 \sim 14.9 \%$ 사이에 분포되었다. 재래식 국간장인 F와 K 제품의 경우 21.0 21.8\%로 다소 높은 염도를 나타내었으며, $\mathrm{M} \sim \mathrm{T}$ 의 산 분해 간장은 $13.0 \sim 16.5 \%$ 정도로 나 타나, 산분해 간장의 염도가 양조간장에 비해 약간 높으며, 재래식으로 제조된 국간장은 대체적으로 높은 염도로 제조되
었음을 알 수 있다. 염수의 농도는 메주로부터 아미노산, peptide 류 및 유리당 등의 용출에 영향을 미치므로, 간장 다당류 의 수율에 영향을 미칠 것이라 사료된다. 간장의 총 질소는 $0.73 \sim 1.42 \%$ 로 나타났으며, 단백질의 분해정도를 알 수 있는 아미노태 질소의 함량은 $254.98 ~ 756.54 \mathrm{mg} \%$ 로 나타나, 제품 에 따라 현저한 차이를 나타내었다. 간장의 총당 함량은 5.30 $137.36 \mathrm{mg} / \mathrm{ml}$, 환원당 함량은 $2.34 ~ 34.79 \mathrm{mg} / \mathrm{ml}$ 로 나타났으 며, 산분해 간장의 경우 환원당 함량이 대체적으로 낮게 나타 났다.

국내 시판 간장으로부터 수용성 다당류를 추출한 후 원료 간장의 양에 대한 추출된 다당류의 양을 수율로 표시하여 Table 3에 나타내었다. 시판 간장 제품으로부터 약 3.43 $\mathrm{mg} / \mathrm{ml}$ 에서부터 최대 $9.53 \mathrm{mg} / \mathrm{ml}$ 의 다당류가 추출되었다. 양 조 간장의 경우 $4.05 ~ 9.53 \mathrm{mg} / \mathrm{ml}$ 이 추출되었으며 산분해 혼 합 간장의 경우 $3.42 ~ 5.46 \mathrm{mg} / \mathrm{ml}$ 의 추출 수율을 나타낸 것으 로 미루어보아, 산분해 간장에 비해 양조간장에서 다당류가 효율적으로 추출된 것을 알 수 있었다. 따라서 간장의 일반성 분 및 함량의 차이에 관한 결과와 함께, 원료 대두의 함량, 발효방법 및 담금 기간의 차이 및 조미를 위한 꿀, 과당, 설탕 등의 당 성분의 첨가에 따라 다당류의 수율에 현저한 차이가 있을 것이라 사료된다. Kobayashi 등[15]은 soy sauce의 양조 중에 생성되는 다당류의 함량은 발효단계에 의한 차이, 원료 (콩껍질, 콩, 밀)에 의하여 차이가 있다고 보고하여 본 연구결 과의 간장의 종류에 따른 다당류의 수율의 차이를 뒷받침 할 수 있다.

Table 2. General composition of commercial soy sauce

\begin{tabular}{|c|c|c|c|c|c|c|}
\hline Sample & $\mathrm{pH}$ & $\begin{array}{l}\text { Salinity } \\
(\%)\end{array}$ & $\begin{array}{l}\text { Total nitrogen } \\
\text { contents }(\%)\end{array}$ & $\begin{array}{l}\text { Amino nitrogen } \\
\text { contents }(\mathrm{mg} \%)\end{array}$ & $\begin{array}{c}\text { Total sugar } \\
\text { contents }(\mathrm{mg} / \mathrm{ml})\end{array}$ & $\begin{array}{l}\text { Reducing sugar } \\
\text { contents }(\mathrm{mg} / \mathrm{ml})\end{array}$ \\
\hline A & 4.60 & 13.0 & 1.14 & 406.29 & 137.36 & 34.79 \\
\hline B & 4.56 & 12.6 & 1.20 & 554.80 & 98.08 & 23.07 \\
\hline $\mathrm{C}$ & 4.59 & 12.4 & 1.18 & 509.96 & 96.62 & 31.82 \\
\hline $\mathrm{D}$ & 4.75 & 13.2 & 1.42 & 712.31 & 85.39 & 17.31 \\
\hline E & 4.75 & 13.6 & 1.17 & 453.92 & 45.13 & 4.78 \\
\hline $\mathrm{F}$ & 4.94 & 21.0 & 0.85 & 336.24 & 5.30 & 2.34 \\
\hline G & 4.89 & 13.6 & 1.32 & 605.23 & 7.12 & 4.24 \\
\hline $\mathrm{H}$ & 4.87 & 13.4 & 1.15 & 588.42 & 14.16 & 2.97 \\
\hline $\mathrm{I}$ & 4.77 & 13.6 & 1.02 & 367.06 & 25.39 & 2.61 \\
\hline $\mathrm{J}$ & 4.66 & 13.4 & 1.35 & 641.66 & 66.97 & 10.27 \\
\hline K & 4.72 & 21.8 & 0.73 & 254.98 & 34.67 & 2.70 \\
\hline $\mathrm{L}$ & 4.69 & 14.9 & 1.52 & 820.99 & 33.90 & 8.02 \\
\hline M & 4.73 & 13.0 & 1.12 & 509.96 & 101.92 & 29.92 \\
\hline $\mathrm{N}$ & 4.83 & 14.1 & 1.15 & 591.22 & 43.46 & 18.66 \\
\hline $\mathrm{O}$ & 4.88 & 16.5 & 1.25 & 714.51 & 13.32 & 6.13 \\
\hline $\mathrm{P}$ & 5.03 & 14.9 & 1.38 & 756.54 & 17.58 & 6.04 \\
\hline $\mathrm{Q}$ & 4.84 & 14.9 & 1.32 & 708.91 & 22.25 & 4.51 \\
\hline $\mathrm{R}$ & 4.83 & 15.1 & 1.35 & 717.31 & 41.72 & 9.73 \\
\hline$S$ & 4.83 & 15.3 & 1.08 & 605.23 & 51.20 & 10.82 \\
\hline $\mathrm{T}$ & 5.08 & 13.8 & 0.95 & 512.77 & 20.30 & 3.61 \\
\hline
\end{tabular}


Table 3. Yield of Kanjang polysaccharide derived from commercial soy sauce

\begin{tabular}{cccc}
\hline Sample & Yield $(\mathrm{mg} / \mathrm{ml})$ & Sample & Yield $(\mathrm{mg} / \mathrm{ml})$ \\
\hline A & $7.31 \pm 0.23$ & $\mathrm{~K}$ & $4.23 \pm 0.25$ \\
B & $9.53 \pm 0.13$ & $\mathrm{~L}$ & $9.31 \pm 0.48$ \\
C & $8.24 \pm 0.08$ & $\mathrm{M}$ & $4.32 \pm 0.32$ \\
D & $9.32 \pm 0.35$ & $\mathrm{~N}$ & $4.13 \pm 0.28$ \\
E & $4.53 \pm 0.18$ & $\mathrm{O}$ & $5.32 \pm 0.42$ \\
F & $4.12 \pm 0.15$ & $\mathrm{P}$ & $5.46 \pm 0.38$ \\
G & $9.13 \pm 0.42$ & $\mathrm{Q}$ & $4.75 \pm 0.32$ \\
H & $6.86 \pm 0.38$ & $\mathrm{R}$ & $3.83 \pm 0.27$ \\
I & $4.05 \pm 0.28$ & $\mathrm{~S}$ & $3.58 \pm 0.16$ \\
J & $7.25 \pm 0.52$ & $\mathrm{~T}$ & $3.42 \pm 0.22$ \\
\hline
\end{tabular}

\section{간장 다당류 KPS의 세포생존율 측정}

국내 시판 간장 유래 다당류 KPS의 HMC-1 세포와 $\mathrm{RBL}-2 \mathrm{H} 3$ 에 대한 세포독성을 조사하기 위하여 추출물을 1 $\mathrm{mg} / \mathrm{ml}$ 농도로 처리하여 MTT assay로 세포 생존률을 조사 한 결과를 Fig.1에 나타내었다. 자극제 PMA와 A23187을 처 리한 대조구 및 KPS를 처리한 구의 MTT assay 결과 HMC-1 세포에서 세포생존율은 85 99\% (Fig. 1A), RBL-2H3 세포에 서 세포생존율은 87 98\% (Fig. 1B)로 대조구와 유의적인 차 이를 나타내지 않아 KPS가 비만세포에 미치는 독성은 없는 것을 확인하였으며, 항알레르기성 탐색 및 histamine 및 $\beta$ -hexosaminidase 분비에 의한 비만세포 탈과립의 억제효과 의 조사에 이용하였다.

\section{간장 다당류 KPS의 histamine 유리 억제효과}

비만세포 내부는 염증유발분자인 histamine 과립이 채워져 있으며, 무해한 물질에 대해서도 탈과립 반응을 하여 알레르 기반응을 일으키며 극단적으로 아나필락시스 반응을 일으키 기도 한다. Histamine은 비만세포의 탈과립에 의해 분비되는 물질 중에서 가장 잘 알려져 있고, 즉시형 과민반응과 관련된 중요한 인자들 중의 하나이다[20, 25]. Histamine은 2 5 $\mathrm{pg} / \mathrm{mast}$ cell 정도로 비만세포 내에 존재하며 기관지 수축, 점액분비 증가, 혈관확장, 혈관투과성 증가 등을 일으킨다[13]. 간장 다당류 KPS가 RBL-2H3 세포에서 histamine 분비에 미 치는 영향을 조사하기 위하여 세포에 $\mathrm{KPS}$ 를 $1 \mathrm{mg} / \mathrm{ml}$ 농도로 처리하여 histamine 분비량을 측정한 후 억제율을 조사한 결 과를 Fig. 2에 나타내었다. 국내 시판 간장 유래 다당류 KPS는 대부분 histamine 유리억제능이 관찰되었으며 그 중 $\mathrm{B}, \mathrm{D}, \mathrm{H}$, $\mathrm{L}, \mathrm{N}$ 구는 $15 \%$ 이상의 높은 유리 억제율을 나타내는 제품으로 확인되었다. Kobayashi 등[15]은 일본식 간장인 쇼유에서 유 래된 shoyu polysaccharide (SPS)가 RBL-2H3 세포에서 histamine의 방출을 효과적으로 저해한다고 보고하여 본 연구와 유사한 결과를 나타내었다.

간장 다당류 KPS의 $\beta$-hexosaminidase 유리 억제효과 외부로부터 이물질이 유입되면 알레르기를 포함한 다양한
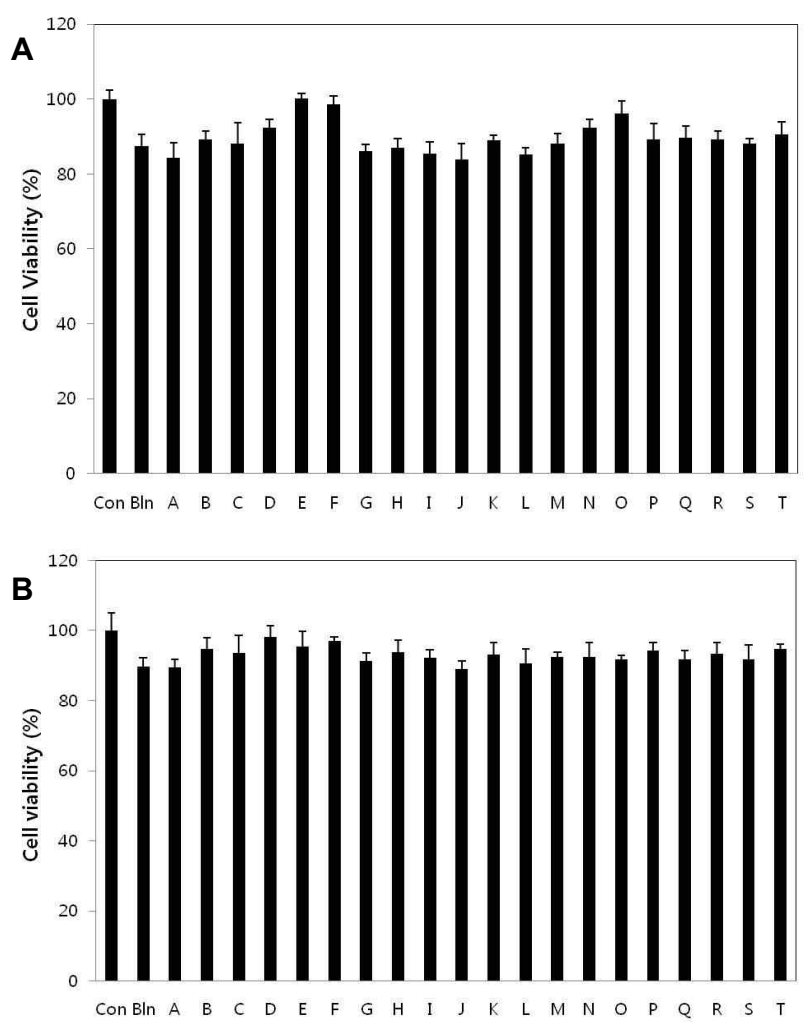

Fig. 1. Effects of KPS on the viability of HMC-1 cells (A) and RBL-2H3 (B). Con: Control (Not treated), Bln: Stimulation (PMA, A23187), A T: KPS treatment+ Stimulation. Data represent the mean \pm SD from three separate experiments.

염증성 질환이 발병한다. 이 과정에서 비만세포 내에 과립에 존재하던 histamine을 비롯한 prostaglandin이나 leukotriene 등의 단백질의 분비와 동시에 $\beta$-hexosaminidase의 분비량도 증가한다. 국내 시판 간장 유래 다당류 KPS가 RBL-2H3 세포 에서 $\beta$-hexosaminidase 분비에 미치는 영향을 조사하기 위하 여 추출물을 $1 \mathrm{mg} / \mathrm{ml}$ 농도로 처리하여 ELISA 법으로 $\beta$ -hexosaminidase 분비량을 측정한 후 억제율을 조사한 결과를 Fig. 3 에 나타내었다. KPS 대부분 $\beta$-hexosaminidase 유리억제 


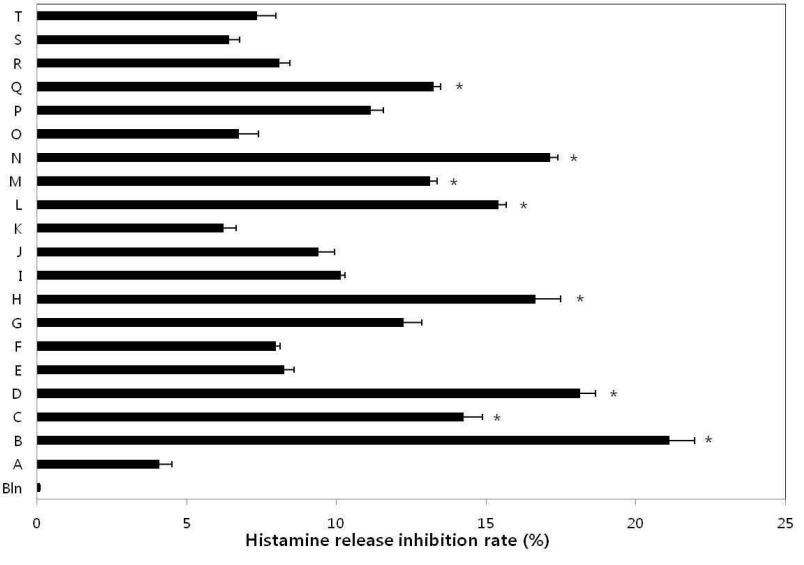

Fig. 2. Inhibitory effects of KPS on histamine release from RBL-2H3 cells. Bln: Stimulation (PMA, A23187), A T: KPS treatment+Stimulation. Data represent the mean \pm SD from three separate experiments. ${ }^{*} p<0.05$, significant compared each blank.

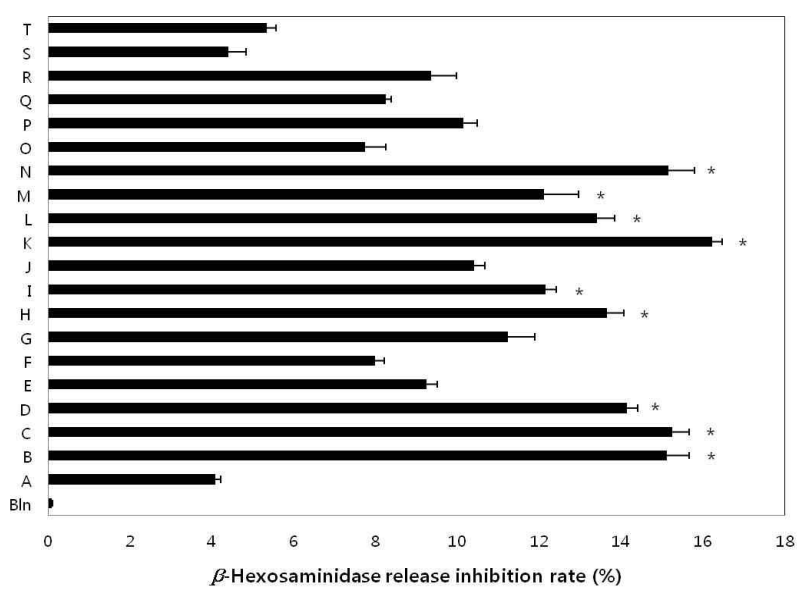

Fig. 3. Inhibitory effects of KPS on $\beta$-hexosaminidase release from RBL-2H3 cells. Bln: Stimulation (PMA, A23187), A T: KPS treatment+Stimulation. Data represent the mean \pm SD from three separate experiments. * $p<0.05$, significant compared each blank.

능이 관찰되었으며, 유의적인 억제효과를 보이는 9 구 중에서 도 특히 B, C, K, N구의 억제율이 우수하여 histamine 유리억 제 효과의 결과와 유사한 양상을 보였다. 특히 재래식 간장인 $\mathrm{K}$ 에서 유래된 다당류는 $16 \%$ 의 억제능을 보였으며, B, C구와 같이 양조간장 유래의 다당류가 산분해 간장 유래 다당류보다 대체적으로 높은 $\beta$-hexosaminidase 억제능을 나타내었다.

\section{간장 다당류 KPS의 염증성 cytokine 분비 억제효과}

TNF- $a$ 는 자가 분비할 뿐만 아니라 IL-6, IL-8과 같은 염증성 cytokine의 유도인자이다[1, 3]. IL-6는 T cell, monocytes, macrophage 등에 의해 생성되는 다면발현 염증성 cytokine이며, $\mathrm{B}$ cell분화의 유도와 $\mathrm{T}$ cell의 성장과 분화 등의 기능을 가진다.

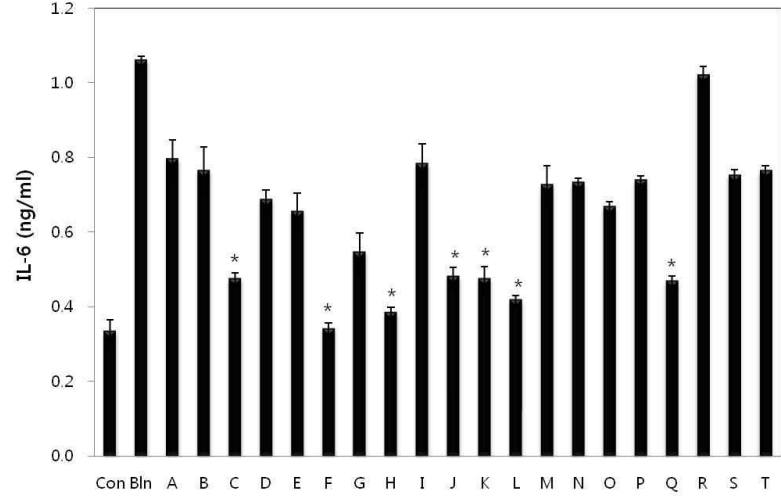

Fig. 4. Effects of KPS on the PMA- and A23187-induced IL-6 secretion from HMC-1 cells. Con: Control (Not treated), Bln: Stimulation (PMA, A23187), A T: KPS treatment+Stimulation. Data represent the mean \pm SD from three separate experiments. ${ }^{*} p<0.05$, significant compared each blank.

IL-8은 류머티즘과 같은 염증질환에서 많이 발견되고[2], 호중 구, $\mathrm{T}$ 림프구, $\mathrm{B}$ 림프구, 호산구와 같은 염증 관련 세포에 영향 을 미친다[22]. KPS가 HMC-1 세포에서 염증성 cytokine인 IL-6의 분비에 미치는 영향을 조사하기 위하여 $\mathrm{KPS}$ 를 1 $\mathrm{mg} / \mathrm{ml}$ 농도로 처리하여 ELISA 법으로 IL-6 분비량을 조사한 결과를 Fig. 4에 나타내었다. 샘플을 처리하지 않은 Blank 구와 비교하여 대부분의 KPS 샘플 처리구에서 IL-6의 분비량이 감 소되는 경향을 보였으며, 특히 간장 $\mathrm{F}$ 와 $\mathrm{H}$ 의 처리에 따른 IL-6 분비량은 각각 $0.34,0.38 \mathrm{ng} / \mathrm{ml}$ 로 Blank 구의 $1.05 \mathrm{ng} / \mathrm{ml}$ 에 비교해 분비량이 현저히 감소하였음을 알 수 있다.

KPS가 HMC-1 세포에서 IL-8의 분비에 미치는 영향을 조사 하기 위하여 $\mathrm{KPS}$ 를 $1 \mathrm{mg} / \mathrm{ml}$ 농도로 처리하여 IL-8 분비량을 조사한 결과를 Fig. 5에 나타내었다. 샘플을 처리하지 않은 Blank 구와 비교하여 대부분의 KPS 샘플 처리구에서 IL-8의 분비량이 감소되는 경향을 보였으며, 특히 간장 $\mathrm{D}$ 와 $\mathrm{H}$ 의 처리 에 따른 IL-8 분비량은 각각 $0.60,0.54 \mathrm{ng} / \mathrm{ml}$ 로 Blank 구의 $1.39 \mathrm{ng} / \mathrm{ml}$ 에 비교해 분비량이 현저히 감소하였음을 알 수 있다.

KPS가 HMC-1 세포에서 TNF- $a$ 의 분비에 미치는 영향을 조사하기 위하여 $\mathrm{KPS}$ 를 $1 \mathrm{mg} / \mathrm{ml}$ 농도로 처리하여 TNF-a 분 비량을 조사한 결과를 Fig. 6에 나타내었다. 샘플을 처리하지 않은 Blank 구의 TNF- $a$ 분비량 $0.62 \mathrm{ng} / \mathrm{ml}$ 과 비교하여 대부 분의 KPS 샘플 처리구에서 TNF- $a$ 의 분비량이 감소되는 경향 을 보였다.

대부분의 시험구에서 염증성 cytokine의 분비 억제효과 관 찰되었으며 대체적으로 산분해 간장보다는 양조간장에서 효 과가 우수한 것으로 나타났다. 이는 각 제품의 원료 사용, 염도 나 $\mathrm{pH}$ 에 따른 원료로부터의 다당류의 용출 정도, 용출된 다당 류의 종류의 차이에 의한 염증성 cytokine이 분비되는 신호전 


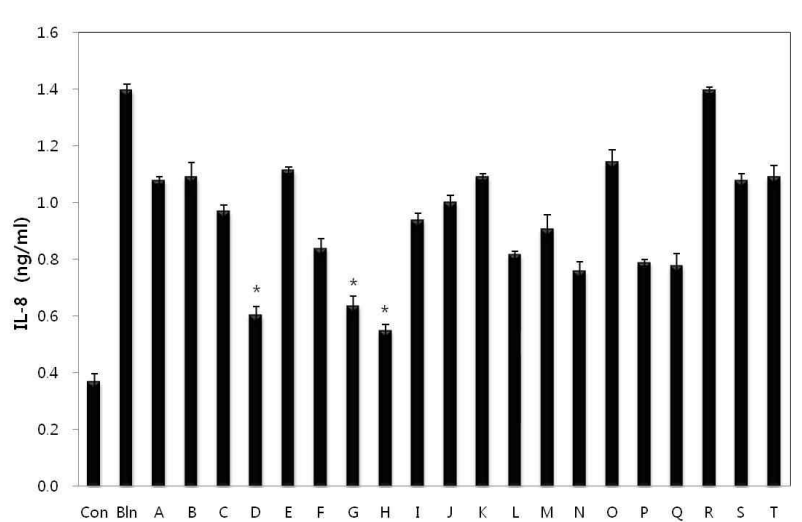

Fig. 5. Effects of KPS on the PMA- and A23187-induced IL-8 secretion from HMC-1 cells. Con: Control (Not treated), Bln: Stimulation (PMA, A23187), A T: KPS treatment+Stimulation. Data represent the mean \pm SD from three separate experiments. ${ }^{*} p<0.05$, significant compared each blank.

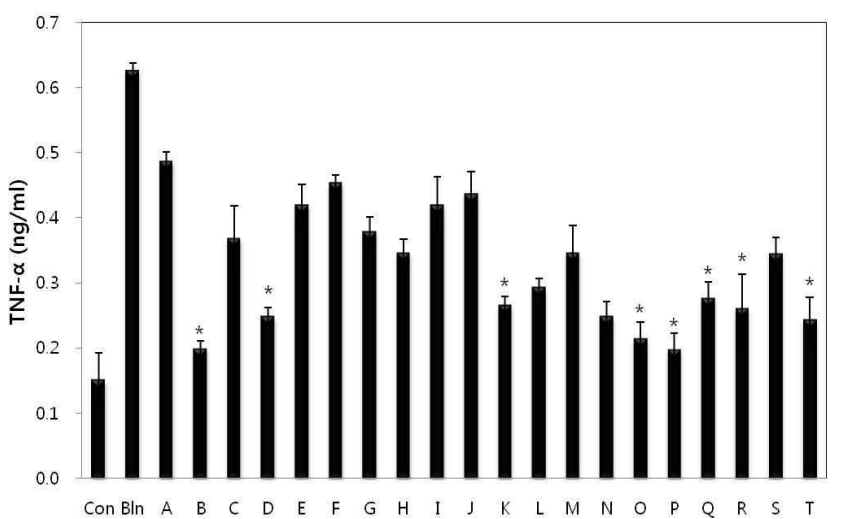

Fig. 6. Effects of KPS on the PMA- and A23187-induced TNF-a secretion from HMC-1 cells. Con: Control (Not treated), Bln: Stimulation (PMA, A23187), A T: KPS treatment+Stimulation. Data represent the mean \pm SD from three separate experiments. ${ }^{*} p<0.05$, significant compared each blank.

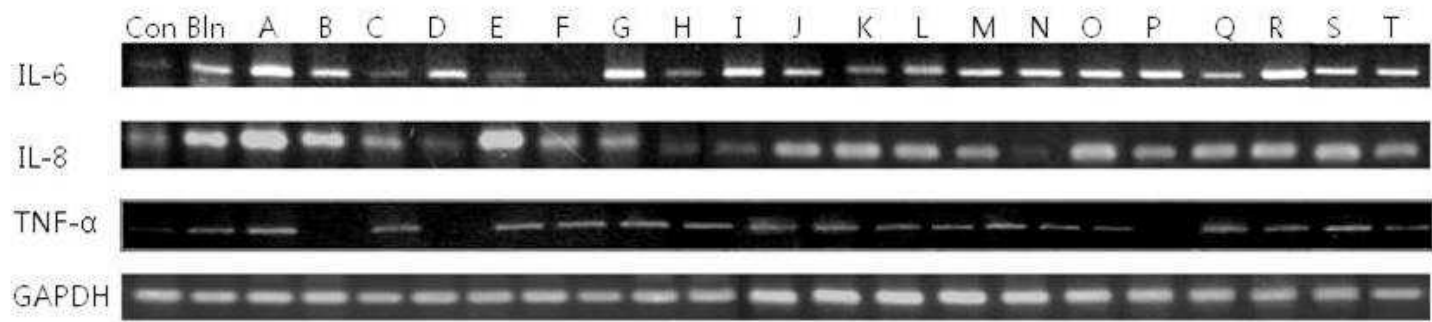

Fig. 7. Effects of KPS on the PMA- and A23187-induced mRNA expression in HMC-1 cells. Con: Control (Not treated), Bln: Stimulation (PMA, A23187), A T: KPS treatment+Stimulation.

달경로의 차단 효과 등에 기인한 것이라 판단된다. 특히 산분 해 간장은 대두 유래의 다당류가 단순분해에 의해 용출되지만 양조간장의 경우 발효 중 미생물이 생성하는 효소에 의한 다 당류뿐만 아니라 발효 미생물 균체 유래의 다당류의 존재까지 기대되므로 더욱 효과적으로 나타난 것이라 사료된다. 최근 감식초[10], 배를 이용한 과실주[4], 복분자주[19] 등 다양한 발 효식품에서 유래된 다당류의 면역증진효과들이 보고되고 있 어, 이러한 결과들은 식품유래의 다당류들의 항염증제, 면역 증진 약품의 대체 식품으로서의 가능성이 있음을 확인시켜 주고 있다.

\section{간장 다당류 $\mathrm{KPS}$ 의 염증성 cytokine mRNA 발현 억제 효과}

KPS가 HMC-1 세포에서 염증성 cytokine의 mRNA 발현에 미치는 영향을 조사하기 위하여 $\mathrm{KPS}$ 를 $1 \mathrm{mg} / \mathrm{ml}$ 농도로 처리 하여 PCR 및 전기영동으로 $\mathrm{mRNA}$ 발현량을 조사한 결과를 Fig. 7에 나타내었다. GAPDH 발현에 따른 cytokine mRNA $\mathrm{IL}-6, \mathrm{IL}-8$ 의 TNF- $a$ 의 발현량을 비교해본 결과 샘플을 처리하 지 않은 Blank 구의 발현량에 비하여 대부분의 구에서 mRNA
발현이 감소함을 확인하였다. 또한 각 유전자의 발현량은 cytokine 방출량과 유사한 경향을 나타내었다. 간장 $\mathrm{B}, \mathrm{C}, \mathrm{H}, \mathrm{I}$ 의 경우 cytokine mRNA의 발현량을 효율적으로 저해하였으며, 특히 산분해 간장 보다는 양조간장 간장유래의 다당류 처리구 에서 mRNA 발현이 효과적으로 억제됨을 확인할 수 있다.

이상의 결과들은 국내 시판 간장에서 유래된 다당류은 $\mathrm{KPS}$ 가 우수한 항염증 효과를 가진다는 것을 시사하며, 양조 간장과 산분해 간장의 다당류 수율 및 항염증 효과의 차이 를 비교하여 간장의 제조방법 및 원료의 차이에 의한 기능 성 다당류의 생산조건을 검토하고 이러한 기능성 성분을 더 욱 증가 - 부각시킬 수 있는 연구를 지속적으로 수행해야 할 것이다.

\section{감사의 글}

본 연구는 농림수산식품기술기획평가원의 고부가가치식품 기술개발사업 연구과제 지원(관리번호: 110122-3)과 BK21 program 지원으로 수행되었기에 이에 감사드립니다. 


\section{References}

1. Arend, W. P. and Dayer, J. M. 1995. Inhibition of the production and effects of interleukin- 1 and tumor necrosis factor alpha in rheumatoid arthritis. Arthritis Rheum 38, 151-160.

2. Baggiolini, M. 2001. Chemokines in pathology and medicine. J Intern Med 250, 91-104.

3. Butler, D. M., Maini, R. N., Feldmann, M. and Brennan, F. M. 1995. Modulation of proinflammatory cytokine release in rheumatoid synovial membrane cell cultures. Comparison of monoclonal anti TNF-alpha antibody with the interleukin-1 receptor antagonist. Eur Cytokine Netw 6, 225-230.

4. Choi, J. H. and Shin, K. S. 2011. Characterization of anti-complementary polysaccharides isolated from fruit wine using Korean pears. J Korean Soc Food Sci Nutr 40, 63-69.

5. Franz, G. 1989. Polysaccharides in pharmacy: Current applications and future concepts. Planta Med 55, 493-497.

6. Fukamizu, R., Jang, M. H. and Miyasaka, M. 2009. The role of eosinophils in allergic inflammation and intestinal immunity. Nippon Rinsho 67, 2088-2093.

7. Heo, Y. and Kim, H. A. 2008. Correlation between skin prick test and enzyme-linked immunosorbent assay using serum for identification of subjects positive to major indoor respiratory allergens. J Env HIth Sci 24, 369-373.

8. Huisman, M. M. H., Schols, H. A. and Voragen, A. G. J. 1998. Cell wall polysaccharides from soybean (Glycine max.) meal. Isolation and characterization. Carbohyd Polym 37, 87-95.

9. Hirayama, K., Sudo, N., Sueyasu, M., Sonoda, J., Chida, Y., Oishi, R. and Kubo, C. 2003. Endogenous glucocorticoids inhibit scratching behavior induced by the administration of compound 48/80 in mice. Eur J Pharmacol 481, 59-65.

10. Hwang, Y. C. and Shin, K. S. 2008. Characterization of immuno-stimulating polysaccharides isolated from Korean persimmon vinegar. Korean J Food Sci Technol 40, 220-227.

11. Joo, D. S., Lee, J. K., Kim, O. S., Cho, S. Y., Lee, D. S., Je, Y. K. and Choi, J. W. 2003. Effect of seatangle oligosaccharide drink on oxidation of serum lipid and bleeding and plasma clotting time in rats fed a hyperlipidemic diet. J Korean Soc Food Sci Nutr 32, 1370-1376.

12. Kikuchi, T. and Sugimoto, H. 1976. Detailed structure of an acidic polysaccharide in soy sauce, confirmed by use of two kinds of purified pectinases. Agricultural Bid Chem 40, 87-92.

13. Kim, J. W. 2008. Inhibitory effects of lactic acid bacteria extracts isolated from Kimchi by extraction methods on the mast cell - mediated inflammatory response. M.D. dissertation, Gyeongsang University, Jinju, Korea.

14. Kim, M. S., Lim, W. K., Cha, J. G., An, N. H., Yoo, S. J., Park, J. H., Kim, H. M. and Lee, Y. M. 2001. The activation of PI3-K and PKC 3 in PMA-induced differentiation of HL-60 cells. Cancer Lett 171, 79-85.

15. Kobayashi, M., Matsushita, H., Yoshida, K., Tsukiyama, R., Sugumura, T. and Yamamoto, K. 2004. In vitro and in vivo anti-allergic activity of soy sauce. Int J Mol Med 14, 879-884.

16. Lebovidge, J. S., Strauch, H., Kalish, L. A. and Schneider, L. C. 2009. Assessment of psychological distress among children and adolescents with food allergy. I Allergy Clin Immunol 124, 1282-1288.

17. Lee, C. Y. 1989. Korean soy seasonings and culture. Food Sci Ind 22, 3-7.

18. Lee, E. J., Whang, E. Y., Whang, K., Lee, I. S. and Yang, S. A. 2009. Anti-allergic effect of Zizania latifolia Turcz extracts. Korean J Food Sci Technol 41, 717-721.

19. Lee, H. O. 2012. Immuno-stimulating activities of mannose-rich polysaccharides isolated from Korean black raspberry wine. Korean J Food Sci Technol 44, 343-349.

20. Miescher, S. M. and Vogel, M. 2002. Molecular aspects of allergy. Mol Aspects Med 23, 413-462.

21. Matsushita, H., Kobatashi, M., Tsukiyama, R. and Yamamoto, K. 2006. In vitro and in vivo immunomodulating activities of Shoyu polysaccharides from soy sauce. Int J Mol Med 17, 905-909.

22. Mukaida, N. 2000. Interleukin-8: an expanding universe beyond neutrophil chemotaxis and activation. Int J Hematd 72, 391-398.

23. Park, K. M., and Lee, B. W. 1998. Extraction and purification of antitumor proein-bound polysaccharides from mycelia of Lentinus edodes. Korean J Food Sci Technol 30, 1236-1242.

24. Paulsen, B. S. 2001. Plant polysaccharides with immunostimulatory activities. Curr Org Chem 5, 939-950.

25. Roitt, I. M., Brostoff, J. and Male, D. K. 2001. Immunology, pp. 323-383, 6th eds., Mosby press, Missouri, USA.

26. Seo, U. K., Lee, J. I., Park, J. H. and Park, Y. K. 2008. The ethylacetate extract of north Kangwhal (Ostericum koreanum) attenuates the inflammatory responses in PMA/A23187stimulated mast cells. Korean J Herbology 23, 81-89.

27. Seo, Y. S. and Shin, K. S. 2012. Immune system-stimulating activities of mucilage polysaccharides isolated from Opuntia humifusa. J Korean Soc Food Sci Nutr 41, 95-102.

28. Shore, P. A., Burkhalter, A. and Cohn, V. H. 1959. A method for the fluorometric assay of histamine in tissue. J Pharmar Exp Ther 127, 182-186.

29. Singh, R., Nath, A., Gupta, P. P., Shulka, M., Khare, S. K. and Kundu, B. 1998. Antiallergic/antiasthmatic activity of oligopeptide related to IgE. Pharmacol Res 37, 353-356.

30. Speyer, C. L., Steffes, C. P. and Ram, J. L. 1999. Effects of vasoactive mediators on the rat lung pericyte: Quantitative analysis of contraction on collagen lattice matrices. Microvasc Res 57, 134-143.

31. Srivastava, R. and Kulshreshtha, D. K. 1989. Bioactive polysaccharides from plant. Phytochemistry 28, 2877-2883.

32. Stuehr, D. J., Cho, H. J., Kwon, N. S., Weise, M. F. and Nathan, C. F. 1991. Purification and characteriazation of the cytokine-induced macrophage nitric oxide synthase: and FAD and FMN containg flavoprotein. Proc Natl Acad Sci 88, 7773-7777.

33. Tzianabos, A. O. 2000. Polysaccharide immunomodulators as therapeutic agents: structural aspects and biological 
function. Clin Microbiol Rev 13, 523-533.

34. Wagner, H. 1990. Search for plant derived natural products with immunostimulatory activity (Recent advances). Pure Appl Chem 62, 1217-1222.

35. Wasser, S. P. 2002. Medicinal mushrooms as a source of antitumor and immunomodulating polysaccharides. Appl Microbiol Biotechnol 60, 258-274.

36. Wedemeyer, J., Tsai, M. and Galli, S. J. 2000. Roles of mast cells and basophils in innate and acquired immunity. Curr Opin Immund 12, 624-631.

37. Yamada, H. and Kiyohara, H. 1989. Bioactive polysaccharides from Chinese herbal medicines. Chinese Med 3, 104-124.

38. Yoon, S. H. 1998. Chemical analysis of acidic proteo-heteroglycans with anti-complementary activity from the hot-water extract of Fomitella fraxinea. Korean J Mycol 26, 502-510.

\section{초록 : 비만세포에서 시판 간장 유래 다당류의 항염증 효과}

고유진 · 이경란 · 류충호*

(경상대학교 응용생명과학부 · 농업생명과학연구원)

간장은 한국의 전통 발효식품으로써 최근 항암 효과, 항균작용, 항산화능, 항혈전 효과 등의 효능이 보고되고 있다. 한국의 간장은 콩과 밀을 주요 원료로 사용한다. 콩의 세포벽으로부터 유래되는 다당류는 효소적 가수분해 에 저항성이 있으므로, 발효가 끝난 후에도 간장에 잔존하게 되며 이것을 간장 유래 다당류(Kanjang polysaccharides, KPS)라 부른다. 본 연구에서는 산분해법과 양조법으로 제조된 시판 간장인 $\mathrm{A} T$ 의 20종의 투석물로 부터 다당류를 제조하고, 비만세포에서 염증성 cytokine의 방출과 mRNA의 발현에 대한 KPS의 효과를 실험함으 로써 항염증 효과를 조사하였다. RBL-2H3 세포에서 KPS의 처리는 histamine과 $\beta$-hexosaminidase의 방출을 현저 히 억제시켰다. 자극된 HMC-1 세포에서 KPS의 처리는 염증성 cytokine인 IL-6, IL-8, TNF-a의 방출 및 mRNA의 발현을 감소시켰다. 특히, 양조간장으로부터 유래된 KPS는 산분해 간장보다 비만세포에서 우수한 항염증 효과를 나타내었다. 따라서, KPS는 알레르기성 염증반응을 억제시키는데 효과적일 것이라 사료된다. 